Int. J. Dev. Biol. 53: 1649-1654 (2009)

doi: $10.1387 / \mathrm{ijdb} .072405 \mathrm{me}$

\title{
Genetic, molecular and cellular approaches to the analysis of maize embryo development
}

\author{
MATILDE JOSÉ-ESTANYOL, IGNACIO LÓPEZ-RIBERA, MIRIAM BASTIDA, TORBEN JARHMANN, \\ NURIA SÁNCHEZ-PONS, CRISTIAN BECERRA, CARLOS M. VICIENT and PERE PUIGDOMĖNECH* \\ Departament de Genètica Molecular Vegetal, Centre de Recerca en Agrigenòmica (CRAG CSIC-IRTA-UAB), \\ Barcelona, Spain
}

\begin{abstract}
The development of embryo structures in plants is essential for the formation of the adult plant organs. In cereals, this process has distinct features which have attracted attention from different points of view. Differential gene expression analyses have been used in order to identify genes useful as molecular markers of certain physiological, molecular or developmental processes. Several maize mutants affected in embryo development have been isolated, but only a fraction of them have been characterized at the molecular level. Molecular markers can be useful in the characterization of embryo defective mutants. Here, we describe the different techniques used in the identification of molecular marker genes for embryo development. We describe in more detail some groups of genes coding for cell wall proteins. We also describe the application of these molecular markers in the characterization of some embryo mutants.
\end{abstract}

KEY WORDS: maize, embryogenesis, cell wall, differential display, mutant

\section{Introduction}

Embryogenesis is the process by which a single-celled zygote develops into a mature embryo. Arabidopsis thaliana, as a model for molecular biologists, has focused in the last decades the interests of many plant embryologists. However, although dicot and monocot species share many processes of embryo development, they also present several differences. Without going any further, the name of these two phylogenetic groups derives from a distinct characteristic of the embryos, the number of cotyledons. Another difference between both groups of plants are that whereas in monocots the dormant embryo has 5-6 leaf primordia in dicots the formation of the first true leaf only occurs after germination (Fig. 1). On the other hand, first cell divisions in the monocot embryos do not follow the precise pattern of cell divisions as they do in dicots. Furthermore, the embryo axis is oblique respect to the suspensor-embryo proper axis in monocot embryos but not in dicots.

Maize (Zea mays) is economically an important crop and has a strong genetic background that includes an extensive collection of mutants affected in embryo development (Weil et al., 2005). On the other hand, maize embryo is large and allows a number of experimental approaches that are more difficult in other species. For these reasons maize has been used as model plant for monocot embryogenesis since one century ago (Vernoud et al., 2005).

\section{Gene discovery in maize embryogenesis}

Understanding the molecular mechanisms that regulate embryogenesis requires the determination of the genes involved in the processes and the functions of the encoded proteins. The characterization of the precise temporal and spatial expression patterns of genes involved in maize embryo development will provide additional candidate genes for functional studies and marker genes useful for the in depth analysis of existing mutants. Marker genes are genes expressed only in determinate cells, only on certain developmental stages and/or only in response to certain stimuli. Expression analyses of marker genes are a widely used tool in developmental biology. In situhybridization analyses allow to identify morphologically aberrant tissues or to establish hierarchical links between genes (Fontanet and Vicient, 2008). Marker genes have been used in the study of plant embryo development in different plant species, including maize (Bastida et al., 2006).

For more than 20 years our group has been working on the identification and characterization of genes involved in different aspects of maize embryo development taking advantage of the

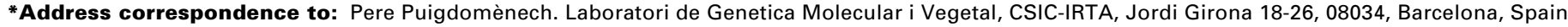
Fax: +34-93-204-5904. e-mail: pprgmp@cid.csic.es - web: http://www.csic-irta.es
} 

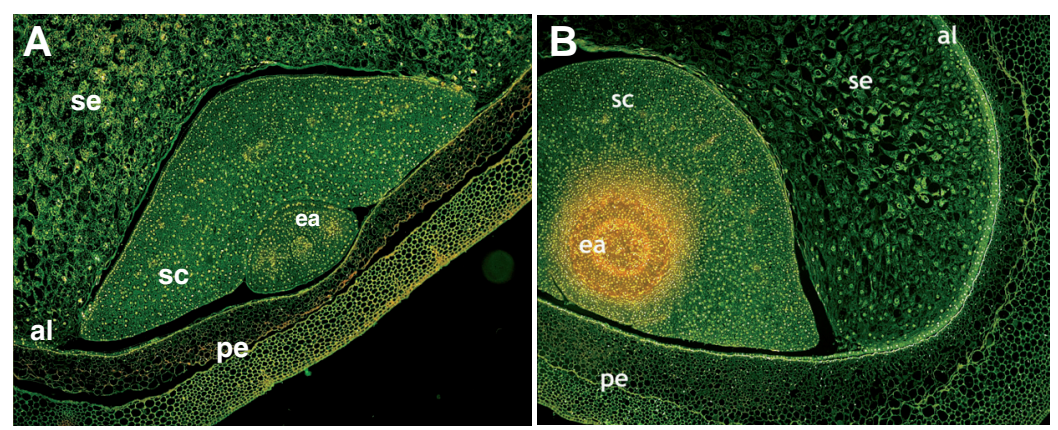

Fig. 1. Anatomy of a mature maize embryo. Transversal sections of mature maize embryos stainied with acryding orange, (A) at the coleoptile level and (B) at the radicle level. Abbreviations: al, aleurone layer; ea, embryo axis; pe, pericarp; se, starchy endosperm; sc, scutellum.

new techniques as they became available. cDNA library construction and sequencing in the 80 s and early 90 s allowed us to identify genes abundantly expressed in maize kernel, such as glutelins and zeins (Prat et al., 1985, 1987), hrgp coding for a cell wall protein (Stiefel et al., 1988), the phospholipid-transfer protein Itp1 (Arondel et al., 1991) or the eukaryotic translation initiation factor 5, elF-5 (Lopez-Ribera et al., 1997; Lopez-Ribera and Puigdomènech, 1999). Differential screening of cDNA libraries allowed us to identify genes predominantly expressed in maize embryo, such as ap17, encoding a clathrin coat assembly protein (Roca etal., 1998), and mark, an atypical receptor kinase (Llompart et al., 2003), among others.

RT-PCR differential display has been widely used to isolate genes with specific expression profiles. ddRT-PCR does not require previous genomic information, allowing its use in noncharacterized species or in organs, tissues or cells in which few transcriptomic studies have been performed and are underrepresented in the available microarray gene sets. Taking in account that, at this moment, maize microarrays available contain only a portion of all maize genes, ddRT-PCR is still an interesting alternative in certain studies. ddRT-PCR have been used by different groups in order to identify genes involved in different aspects of maize seed and embryo development (Magnard et al., 2004).

We have compared different mRNA populations using ddRTPCR to identify maize genes involved in embryo development. We dissected 12 dap embryos into three parts: apical or shoot, central or node, and basal or root. Genes expressed in the different regions are likely to be involved in the formation of different structures or organs. We have identified a gene, $Z \mathrm{mPRL}$, which is more abundantly expressed in the embryo shoot region (Bastida et al., 2002). ZmPRL encodes a MCM7 protein required for DNA replication to ensure that only one round of replication takes place in each cell cycle. In situ hybridization shows high levels of expression in actively proliferating cells which is in agreement with the expected pattern for a gene related to cell cycle and proliferation.

We have also compared wild with longcell mutant type mRNA kernel populations. In longcell mutant embryo development is arrested in the early stages of embryogenesis (Graziano et al., 2003; Bastida et al., 2006). We have identified and verified the differential expression of twelve genes. For example, a gene coding for a 1-L-myo-inositol 1 phosphate synthase (MIPS) is under-regulated in longcell kernels. This enzyme catalyzes the conversion of glucose-6-phosphate to myoinositol 1-phosphate, which is the first product in the biosynthetic pathway of myo-inositol, which is, itself, the starting material for phytic acid synthesis. Other genes identified by differential display assay include genes encoding knotted, CDC48, an RNA binding protein, scarecrow, a protein kinase, a protease, cytochrome b245, $\beta$-chain NADpH oxidase, pectate lyase-like protein, histone deacetylase $2 \mathrm{~b}$ and cyclophilin (Bastida et al., 2006).

Large-scale expression analysis is an important tool for identifying differentially expressed and functionally important development-regulated genes, as well as revealing the genetic networks in which they are involved. This expression analysis can be achieved using techniques such as EST sequence profile, serial analysis of gene expression (SAGE), massively parallel signature sequencing (MPSS) or microarray hybridization. Important efforts have been done in the characterization of the maize transcriptome. More than one million maize EST sequences have been deposited in Genebank dbEST database (release 011108) and near $10 \%$ corresponded to libraries constructed from kernels or parts of the kernel. MPSS and SAGE have been used to identify expressed genes in some maize organs, but they have not been extensively used for embryogenesis studies. Different microarray platforms have been developed for maize but they have been only slightly used for maize embryo developmental studies.

\section{Mutant analysis of maize embryogenesis}

Mutant analysis represents one of the most reliable approaches to identify genes involved in plant embryo development. A number of large screenings for embryo mutants have provided a collection of nearly 750 loci essential for embryogenesis (Tzafrir et al., 2003) and have led to the idea that, although few key regulatory genes exist, correct embryo development requires the sequential and coordinated action of genes of many different functional categories. Embryo lethality is one of the most common mutant traits in plants (Magnard et al. 2004) and several maize mutants affected in embryo development have been obtained from stocks containing active transposable elements (Dellaporta and Moreno, 1994) or by EMS mutagenization (Sheridan and Neuffer, 1982). Morphological, cytological analysis, together with the use of gene markers have provided valuable information on the regulation of embryogenesis in maize and determined, for example, that a interaction exists between endosperm and embryo during seed development (Sheridan and Neuffer, 1982), that embryo development can be blocked at a variety of different stages, that the arrest of development can imply necrosis or not, and can be associated to morphological alterations or not (Vernoud et al., 2005).

We have been working in the phenotypic analysis of two defective kernel mutants: lacchrima and longcell. Mutant lacchrima is a recessive defective kernel (dek) mutant causing severe morphological alterations in the embryo and a reduction in endosperm size. In lacchrima, the embryo fails to acquire bilateral symmetry and is a tear drop shape. Similar phenotypes 
have been described and in several cases are due to perturbations of auxin function such as auxin synthesis, transport, perception or degradation (Berleth and Sachs, 2001).

On the other hand, longcell mutant is defective in embryo and endosperm development (Graziano et al., 2003). The mutant embryos are variable in shape but development is always blocked before the early coleoptilar stage. Although the endosperm is reduced in size, it has the typical vitreous texture, basal endosperm, transfer and aleurone layers (Bastida et al., 2006). Despite their abnormal shape, mutant embryos have often a suspensor-, scutellum-, embryo axis- and radicle-like structures, but they never develop the shoot apical meristem (SAM). Cells in the scutellum-like structure are bigger and more irregular in shape than in the embryo axis-like structure. Scanning electron microscopy shows that cells in longce//embryos are abnormally long compared to the wild type, first appearing in the scutellum-like structure, next to where the SAM should be, and spreading throughout the embryo. The expression of several marker genes was examined in the longce//mutants. During normal development, $\gamma$-zein mRNA accumulates in the subaleurone cells in the endosperm, but in longcell mutant $\gamma$ zein mRNA is accumulated in all endosperm cells (Bastida et al., 2006). The patterns of expression of genes involved in basic metabolic processes, such as glyceraldehyde phosphate dehydrogenase, acyl carrier protein (AP17) and a clathrin adapter protein, are not severely affected by the longcell mutation during early and mid embryogenesis. Genes that are only expressed after germination in wild type embryos are expressed during kernel development in longcell, for example, $\alpha$ amylase and $\beta$-glucanase. Differential display allowed us to isolate genes up- and down-regulated in the mutant. Mutant embryos die during development at around 35 dap. Cell death in these embryos shows some characteristics of a programmed cell death process and is not necrotic. Different genes coding for hydrolytic enzymes and genes involved in oxidative stress are up-regulated in the mutant. Nuclei of mutant cells are positive in TUNEL staining, which is characteristic of programmed cell death process and not found in necrotic cells.

Another aspect of mutant analysis is the characterization of the genes whose mutation produces an embryo defective phenotype. Two different approaches can be use: forward and reverse genetics. Forward genetics starts with a mutant line and follows the identification of the mutated gene, and reverse genetics starts with a gene and follows the isolation of lines in which the function of the gene has been altered. Forward genetics in maize have been demonstrated to be extremely difficult and have been only done for a few transposon tagged embryo defective mutants. Mutant emb8516 is produced by an insertion in the ZmPRPL35 gene, which encodes a plastid ribosomal protein (Magnard et al., 2004; Ma et al., 2004). Mutant empty pericarp2 (emp2) is the result of an insertion in a gene encoding a heat shock binding protein ( $H S B P$ ) (Fu et al., 2002), while empty pericarp4 has an insertion in a gene which encodes a protein containing a pentatricopeptide repeat, located in the mitochondria and possibly involved in the regulation of expression of a small subset of mitochondrial transcripts in the endosperm (Dolfini et al., 2007; Gutierrez-Marcos et al., 2007).

Resources for maize reverse genetics have been developed in the last years (Weil et al., 2005). These systems are based in the production of a collection of genomic DNAs from a population of mutagenized plants by transposon insertion or by chemical mutagenization. These DNA pools are screened for the detection of insertions or point mutations in the desired gene. Screening in the case of TILLING (Targeting Induced Local Lesions in Genomes) is based on enzymatic- and electrophoresis-based mismatch detection and in the case of transposon tagged populations is based on PCR or on sequence comparation against databases of transposon flanking sequences (FSTs). Transposon tagged populations has been mainly produced by crossing Mutator-active lines with inbred or hybrid lines (Settles et al., 2007). These systems will provide valuable information for maize embryologists. For example, two mutants, zmsmu2-1 and zmsmu2-3 resulted from insertion of a Mutator $(\mathrm{Mu})$ transposable element show alterations in meristem development (Chung et al., 2007). Zmsmu2 gene is homologous to the nematode gene, smu-2, which is involved in RNA splicing.

\section{Cell wall proteins, cell division and embryogenesis}

Progression through the cell cycle during embryogenesis requires the accurate assembly of a new cell wall in the correct orientation. Signaling between dividing cells directs the choice of developmental pathway, and some of these signals are thought to arise from the cell wall. Soluble signals such as arabinogalactan proteins (AGPs) play a role in the control of somatic embryogenesis, while carbohydrate oligomers act on morphogenic pathways. During biosynthesis of the new cell walls, cellulose is polymerized at the plasma membrane and deposited directly in the wall, but most of the other matrix components are synthesised in Golgi and delivered to the cell plate by secretory vesicles, guided by a network of microtubules and microfilaments (Lerouxel et al., 2006). Mutations in proteins involved in these processes, such as emb30/gnom, knolle or hinkel, alter Arabidopsis embryo development. Mutation in an Arabidopsis structural protein, the hydroxyproline-rich glycoprotein (HRGP) $\mathrm{RSH}$, has also been shown to produce defective positioning of the cell plate during cytokinesis in cells of the developing embryo. Similar HRGPs cell wall structural proteins have been characterized in maize, between them we must consider AGPs, extensins, proline-rich proteins (PRPs) and hybrid proline-rich proteins (HyPRPs) that present different degrees of glycosilation. Sugars are added to these proteins mainly to hydroxyproline and serine by o-glycosidic linkages. All of them present a signal peptide to be exported out of the cell. Between the main maize cell wall structural proteins until now described we can mention:

AGPs: AGPs are known acidic proteoglycans highly glycosylated with arabinogalactan chains generally through HypGal and often contain Hyp/Pro-Ala or Ala-Hyp/Pro motifs. An AGP protein, HRGP, was purified from maize cultured cells and it shares glycosylation patterns with both extensins and AGPs. Later maize AGPs epitopes distribution was analyzed on the surface of maize embryogenic calli using JIM4 AGP monoclonal antibodies by scanning electron microscopy (SEM). This AGP epitope was distributed along callus surfaces being specifically enriched in the outer extracellular layers covering compact clusters of embryogenic meristematic callus cells (Samaj etal., 1999). 
AGPs have been also recently identified when secreted during maize microspore culture to allow androgenesis (Borderies et al., 2004) with antibodies that recognize AGPs epitopes and have shown that AGPs may be used to stimulate the development of microspores to embryogenesis.

Extensins: Extensins are basic glycoproteins. A maize extensin protein (ZmHRGP) has been purified from maize cells and pericarp cell walls and its cDNA was cloned from a coleoptile library (Stiefel et al., 1988, 1990) and the homologous gene cloned and sequenced from different maize lines and closely related species such as teosinte (Stieffel et al., 1990; Raz et al., 1992), sorghum (Raz et al. 1991) and rice (Caelles et al., 1992). The ZmHRGP protein was initially immunodetected in maize root tip cell walls of young maize seedlings (Ludevid et al., 1990). ZmHRGP gene expression was mainly associated to actively dividing tissues and involved in the response to wounding (Ludevid et al., 1990), ethylene (Tagu et al., 1992), symbiotic infection with Glomus versiforme (Balestrini et al., 1994, 1997) and pathogens, being induced by ascorbic acid and reduced glutathione (Garcia-Muniz et al., 1998). During seed development ZmHRGP gene expression is found in the exocarp (Jose-Estanyol and Puigdomènech., 2000 ) but it is also expressed in the embryo (Jose-Estanyol and Puigdomènech, 1998a). At the pro-embryo stage $Z m H R G P$ is expressed in the basal cells and in the suspensor cells during the transition stage, and in cells surrounding the emerging shoot meristem at the coleoptilar stage. Once the embryo axis has developed, $Z m H R G P$ gene expression is localized in the prometaxylem and procambium cells of the vascular cylinder in the radicle, and in the prometaxylem of the coleoptile and leaf primordia. No gene expression is observed in the scutellum (RuizAvila et al., 1991, 1992). ZmHRGP gene expression transiently increases at the end of morphogenesis, when ABA accumulates, but is finally repressed. Similar behaviour is observed when excised immature embryos are incubated with the hormone. In both cases a change in the cellular gene expression pattern has been observed (Jose-Estanyol and Puigdomènech, 1998b). Expression of the gene in the developing flower (Josè-Estanyol and Puigdomènech, 1998a) and growing pollen tubes (Torres et al., 1995) have also been reported. The high level of $Z m H R G P$ gene expression in the silk has allowed to identify multiple bands by Northern analysis that have been explained as secondary structures of zmHRGP mRNA (Garcia-Muniz et al. 1999). Functional promoter analysis revealed different regulatory elements in maize (Vallés et al. 1991, Tagu et al. 1992) and rice (Guo et al., 1994) HRGP promoter regions, the latter not being responsive to wounding. In the presence of the 3' untranslated region, the levels of GUS activity directed by the maize HRGP and 35S promoters could be modulated (Menossi et al., 2003). The zmHRGP promoter has also shown to be responsive to elicitors, etephon and ethylene (Menossi et al., 1997).

Two more extensins, Pex1 and Pex2, have been also characterized in maize. Their amino acid sequence is highly conserved. They are complex multidomain proteins with a globular $\mathrm{N}$-domain including a leucine-rich repeat (LRR) with an adjacent cysteinerich region, a transition zone and a extensin-like domain. Immunocytochemical analysis at the ultrastructural level localized the Pex1 protein to the intine in mature pollen and to the callosic sheath of the pollen tube wall in germinating pollen. It has been proposed that Pex proteins play a role in pollen tube growth during pollination where extensin-like domains can anchor the protein to the cell wall while the globular one could be involved in interactions to each other or to pistil ligands.

PRPs: maize PRP has a PEPK repeat in which acidic and basic amino acid residues alternate with proline, giving a flat hydropathy profile suggesting an extended fibre-like structure that may interact with itself and/or with other cell wall components through ionic interactions (Vignols et al., 1999). ZmPRP is expressed in almost all tissues analyzed with the exception of endosperm and embryo. It is strongly expressed in the pericarp of the developing seeds and in cortex cells surrounding metaxylem of germinated maize plants, but is absent in phloem.

HyPRPs: $Z m H y P R P$, a marker of scutellum differentiation (Jose-Estanyol and Puigdomènech, 1998a), is a gene mainly expressed in the embryo (Jose-Estanyol et al., 1992) and to a lesser extent in the endocarp (Jose-Estanyol and Puigdomènech, 2000). Once ABA is induced, after morphogenesis, ZmHyPRP gene expression is repressed by the hormone. ZmHyPRP promoter regulatory elements have been analyzed by stable and transient maize transformation after promoter fusion to GUS (Jose-Estanyol et al., 2005). The coding region of ZmHyPRP encodes a protein with a signal peptide and two other domains, a proline-rich repetitive domain and a C-terminal hydrophobic domain with a pattern of eight cysteines also present in proteins such as cell wall LTPS, dicotyledonous $2 \mathrm{~S}$ albumin reserve proteins and in cereal seed amylase and trypsin inhibitors. The structure of this eight-cysteine motif (8CM) domain in all these different families of proteins is a structural scaffold of four conserved helical regions connected by variable loops, stabilized by four cysteine bridges (Jose-Estanyol et al., 2004).

\section{The future of maize embryology}

Technical limitations have always accompanied plant embryologists, especially when studying early events in embryo development. The size and position of the embryos, surrounded by other tissues, and their rapid development make it difficult to get enough material for many molecular analyses. The frequent lethality of the mutants affected in embryo development is an additional problem. It is then not surprising that plant embryology has co-evolved with technical progress. The publication of a draft of the maize genome sequence together with the availability of literally millions of EST sequences represents a milestone in maize embryology, allowing the design of arrays for transcriptomic assays with a more complete set of genes. Due to the size and complexity of the embryos, microdissection techniques in combination with transcriptomics represent a major opportunity to determine temporal and spatial patterns of expression of all genes involved in embryo development. High-throughput in situ mRNA hybridization will provide a more complete representation of gene expression patterns. The accumulation of enough material is the main problem in proteomic and metabolomic analysis on maize embryos in very early stages of development, but, due to the relative large size of the maize embryo compared to other plants provides good opportunities to study mid and late embryogenesis using these technologies.

Genomics, transcriptomics and proteomics will provide clues to the patterns of expression and protein accumulation of different genes involved in embryo development, but not necessarily their 
molecular functions. Mutant analysis will help to fill this gap. Functional genomics has been a key tool in studying embryogenesis in Arabidopsis but its potential has not yet been totally exploited in monocots such as maize. Here, the development of large scale TILLING platforms for maize is of great importance.

In conclusion, our understanding of the regulation of maize embryogenesis is evolving rapidly as many of the approaches described here are underway. The availability of genomic sequences in maize and other organisms, and the development of high-scale gene expression analyses, allowed the identification of genes involved in specific molecular, physiological or developmental processes that can be usefull as molecular markers in the characterization of, for example, new mutants, as we did for longcell maize mutant (Bastida et al., 2006). Unfortunately, proteomic or metabolomic analysis on early maize embryos is still difficult but miniaturization in the future may provide opportunities also in these fields. Exciting times are coming for maize embryologists.

\section{Acknowledgments \\ In Memoriam: Dr Virginia Stiefel. This work was carried out thanks to different grants from Plan Nacional de Investigación Científica y Técnica and a grant from the program MAZE, European Union, and within the framework of Xarxa de Referència de Biotecnologia de la Generalitat de Catalunya.}

\section{References}

ARONDEL, V., TCHANG, F., BAILLET, B., VIGNOLS, F., GRELLET, F., DELSENY, M., KADER, J.C. and PUIGDOMĖNECH, P. (1991). Multiple mRNA coding for phospholipid-transfer protein from Zea mays arise from alternative splicing. Gene 99: 133-136.

BALESTRINI, R., JOSE-ESTANYOL, M., PUIGDOMĖNECH, P. and BONFANTE P. (1997). Hydroxyproline-rich glycoprotein mRNA accumulation in maize root cells colonized by an arbuscular mycorrhizal fungus as revealed by in situ hybridization. Protoplasma 198: 36-42.

BALESTRINI, R., ROMERA, C., PUIGDOMÈNECH, P. and BONFANTE, P. (1994). Location of a cell wall hydroxyproline-rich glycoprotein, cellulose and $\beta-1,3-$ glucans in apical and differentiated regions of maize mycorrhizal roots. Planta 195: 201-209.

BASTIDA, M. and PUIGDOMĖNECH, P. (2002). Specific expression of ZmPRL, the maize homologue of MCM7, during early embryogenesis. Plant Sci. 162:97106.

BASTIDA, M., GRAZIANO, E., ROCA, R., LOPEZ, I., SANCHEZ-PONS, N., PUIGDOMĖNECH, P. and VICIENT, C.M. (2006). A maize defective-kernel mutant (longcell) characterized by tubular cells, severe morphological alterations and induction of cell death. Planta 223: 755-768.

BERLETH, T. and SACHS, T. (2001). Plant morphogenesis: long-distance coordination and local patterning. Curr. Opin. Plant Biol. 4: 57-62.

BORDERIES, G., LE BECHEC, M., ROSSIGNOL, M., LAFITTE, C., LE DEUNFF, E., BECKERT, M., DUMAS, C. and MATTHYS-ROCHON, E. (2004). Characterization of proteins secreted during maize microspore culture: arabinogalactan proteins (AGPs) stimulate embryo development. Eur. J. Cell Biol. 83: 205-212.

CAELLES, C., DELSENY, M. and PUIGDOMĖNECH, P. (1992). The hydroxyproline-rich glycoprotein gene from Oryza sativa. Plant Mol. Biol. 18: 617-619.

CHUNG, T., KIM, C.S., NGUYEN, H.N., MEELEY, R.B. and LARKINS, B.A. (2007). The Maize Zmsmu2 Gene Encodes a Putative RNA-Splicing Factor That Affects Protein Synthesis and RNA Processing during Endosperm Development. Plant Phys. 144: 821-835.

DELLAPORTA, S.L. and MORENO, S.A. (1994). Gene tagging with Ac/Dc elements in maize. In The Maize Handbook (Ed. M. Freeling and V. Walbot). Springer Verlag, New York, pp. 526-533.

DOLFINI, S., CONSONNI, G., VIOTTI, C., DAL PRA, M., SALTINI, G., GIULINI, A.,
PILU, R., MALGIOGLIO, A. and GAVAZZI. G. (2007). A mutational approach to the study of seed development in maize. J. Exp. Bot. 58:1197-1205

FONTANET, P. and VICIENT, C.M. (2008) Maize embryogenesis. In Plant Embryogenesis (Ed. M.F. Suárez and P.V. Bozhkov). Humana Press, Totowa, pp. 1729.

FU, S., MEELEY, R. and SCANLON, J. (2002). empty pericarp2 encodes a negative regulator of the Heat Shock response and is required for maize embryogenesis. Plant Cel/14: 3119-3132.

GARCÍA-MUNIZ, N., MARTÍNEZ-IZQUIERDO, J.A. and PUIGDOMÈNECH, P. (1999). Unusual electrophoretic mobility of maize Hrgp mRNA. Plant Phys. Bioch. 37: 605-610.

GARCIA-MUNIZ, N., MARTINEZ-IZQUIERDO, J.A. and PUIGDOMÈNECH, P. (1998). Induction of mRNA accumulation corresponding to a gene encoding a cell wall hydroxyproline-rich glycoprotein by fungal elicitors. Plant Mol. Biol. 38 : 623-632.

GRAZIANO, E., BASTIDA, M., STIEFEL, V. and PUIGDOMĖNECH, P. (2003) Longcell, a mutant from maize producing a distorted embryo and generalized cell death. In The Biology of Seeds: Recent Research Advances (Ed. G. Nicolás and K.J. Bradford). CABI Publishing, Oxon, pp 25-32.

GUO, Y., DELSENY, M. and PUIGDOMĖNECH, P. (1994). mRNA accumulation and promoter activity of the gene coding for a hydroxyproline-rich glycoprotein in Oryza sativa. Plant Mol Biol. 25: 159-165.

GUTIERREZ-MARCOS, J.F., DAL PRA, M., GIULINI, A., COSTA, L.M., GAVAZZI, G., CORDElieR, S., SELlam, O., TATOUT, C., PAUL, W., PEREZ, P. DICKINSON, H.G. and CONSONNI, G. (2007). Empty pericarp4 Encodes a Mitochondrion-Targeted Pentatricopeptide Repeat Protein Necessary for Seed Development and Plant Growth in Maize. Plant Cel/19: 196-210.

JOSE-ESTANYOL, M., RUIZ-AVILA, L. and PUIGDOMĖNECH, P. (1992). A maize embryo-specific gene encodes a proline-rich and hydrophobic protein. Plant Cel/4: 413- 423.

JOSE-ESTANYOL, M. and PUIGDOMÈNECH, P. (1998a). Developmental and hormonal regulation of genes coding for proline-rich proteins in female inflorescences and kernels of maize. Plant Phys. 116: 485-494.

JOSE-ESTANYOL, M. and PUIGDOMÈNECH, P. (1998b). Rapid changes induced in developmental programmes of the maize embryo detected by analysis of the expression of genes encoding proline-rich proteins. FEBS Lett. 422: 400-402.

JOSE-ESTANYOL, M. and PUIGDOMĖNECH, P. (2000). Plant cell wall glycoproteins and their genes. Plant Phys. Bioch. 38: 97-108.

JOSE-ESTANYOL M., GOMIS-RÜTH, X. and PUIGDOMÈNECH, P. (2004). The eight cysteine motif, a versatile structure in plant proteins. Plant Phys. Bioch. 42 : 355-365.

JOSE-ESTANYOL, M., PÉREZ, P. and PUIGDOMĖNECH, P. (2005). Expression of the promoter of $H y P R P$, an embryo-specific gene from Zea maysin maize and tobacco transgenic plants. Gene 356: 146-152.

LEROUXEL, O., CAVALIER, D.M., LIEPMAN, A.H. and KEEGSTRA, K. (2006) Biosynthesis of plant cell wall polysaccharides - a complex process. Curr. Opin. Plant Biol. 9: 621-630.

LLOMPART, B., CASTELLS, E., RÍO, A., ROCA, R., FERRANDO, A., STIEFEL, V., PUIGDOMĖNECH, P. and CASACUBERTA, J.M. (2003). The direct activation of MIK, a germinal center kinase (GCK)-like kinase, by MARK, a maize atypical receptor kinase, suggests a new mechanism for signaling through kinase-dead receptors. J. Biol. Chem. 278: 48105-48111.

LOPEZ-RIBERA, I. and PUIGDOMĖNECH, P. (1999). Structure, organization and expression of the eukaryotic translation initiation factor 5, elF-5, gene in Zea mays. Gene 240: 355-359.

LOPEZ-RIBERA, I., RUIZ-AVILA, L. and PUIGDOMĖNECH, P. (1997). The eukaryotic translation initiation factor 5 , elF-5, a protein from Zea mays, containing a zinc-finger structure, binds nucleic acids in a zinc-dependent manner. Biochem. Biophys. Res. Commun. 236: 510-516.

LUDEVID, M.D., RUIZ-AVILA, L., VALLÉS, M.P., STIEFEL, V., TORRENT, M. TORNÉ, J.M. and PUIGDOMĖNECH, P. (1990). Expression of genes for cellwall proteins in dividing and wounded tissues of Zea mays L. Planta 180: 524529.

MA, Z. and DOONER, H.K. (2004). A mutation in the nuclear-encoded plastid ribosomal protein S9 leads to early embryo lethality in maize. Plant J. 37: 92-103

MAGNARD, J.L., HECKEL, T., MASSONNEAU, A., WISNIEWSKI, J.P., 
CORDELIER, S., LASSAGNE, H., PEREZ, P., DUMAS, C. and ROGOWSKY, P.M. (2004). Morphogenesis of maize embryos requires $Z m P R P L 35-1$ encoding a plastid ribosomal protein. Plant Phys. 134: 649-663.

MENOSSI, M., MARTÍNEZ-IZQUIERDO, J.A. and PUIGDOMÈNECH, P. (1997). Promoter tissue specific activity and ethylene control of the gene coding for the maize hydroxyproline-rich glycoprotein in maize cells transformed by particle bombardment. Plant Sci. 125: 189-200.

MENOSSI, M., RABANEDA, F., PUIGDOMĖNECH, P. and MARTINEZ-IZQUIERDO, J.A. (2003). Analysis of regulatory elements of the promoter and the $3^{\prime}$ untranslated region of the maize Hrgp gene coding for a cell wall protein. Plant Cell Rep. 21: 916-923.

PRAT, S,, CORTADAS, J., PUIGDOMÈNECH, P. and PALAU, J. (1985) Nucleic acid (CDNA) and amino acid sequences of the maize endosperm protein glutelin-2. Nucl. Ac. Res. 13: 1493-504.

PRAT, S., PEREZ-GRAU, L. and PUIGDOMÈNECH, P. (1987). Multiple variability in the sequence of a family of maize endosperm proteins. Gene. 52: 41-49.

RAZ, R., CRETIN, C., PUIGDOMÈNECH, P. and MARTINEZ-IZQUIERDO, J.A. (1991). The sequence of a hydroxyproline-rich glycoprotein gene from Sorghum vulgare. Plant Mol Biol. 16: 365-367.

RAZ, R, JOSE, M., MOYA, A., MARTINEZ-IZQUIERDO, J.A. and PUIGDOMÈNECH, P. (1992). Different mechanisms generating sequence variability are revealed in distinct regions of the hydroxyproline-rich glycoprotein gene from maize and related species. Mol Gen Genet. 233: 252-259.

ROCA, R, STIEFEL, V. and PUIGDOMĖNECH P. (1998). Characterization of the sequence coding for the clathrin coat assembly protein AP17 (2) associated with the plasma membrane from Zea mays $L$ and constitutive expression of its gene. Gene 208: 67-72.

RUIZ-AVILA, L., LUDEVID, M.D. and PUIGDOMÈNECH, P. (1991). Differential expression of a hydroxyproline-rich cell wall protein gene in embryonic tissues of Zea mays L. Planta 184: 130-136.

RUIZ-AVILA, L., BURGESS, S.R., STIEFEL, V., LUDEVID, M.D. and PUIGDOMĖNECH, P. (1992). Accumulation of cell wall hydroxyproline-rich glycoprotein mRNA is an early event in maize embryo cell differentiation. Proc Natl Acad Sc. USA 89: 2414-2418.

SAMAJ, J., ENSIKAT, H.J., BALUSKA, F., KNOX, J.P., BARTHLOTT, W. and VOLKMANN, D. (1999). Immunogold localization of plant surface arabinogalactan-proteins using glycerol liquid substitution and scanning electron microscopy. J. Microsc. 193: 150-157.
SETTLES, A.M., HOLDING, D.R., TAN, B.C., LATSHAW, S.P., LIU, J., SUZUKI, M., LI, L., O'BRIEN, B.A., FAJARDO, D.S., WROCLAWSKA, E., TSEUNG, C.W., LAI, J, HUNTER, C.T. 3rd, AVIGNE, W.T., BAIER, J., MESSING, J., HANNAH, L.C., KOCH, K.E., BECRAFT, P.W., LARKINS, B.A. and MCCARTY, D.R. (2007). Sequence-indexed mutations in maize using the UniformMu transposon-tagging population. BMC Genom. 8: 116.

SHERIDAN W.F. and M.G. NEUFFER, (1982). Maize developmental mutants. Embryos unable to form leaf primordia. J. Hered. 73: 318-329.

STIEFEL, V., PÉREZ-GRAU, L., ALBERICIO, F., GIRALT, E., RUIZ-AVILA, L., LUDEVID, D. and PUIGDOMĖNECH P. (1988). Molecular cloning of cDNAs encoding a putative cell wall protein from Zea mays and immunological identification of related polypeptides. Plant Mol Biol. 11: 483-493.

STIEFEL, V., RUIZ-AVILA, L., RAZ, R., VALLÉS, M.P., GOMEZ, J., PAGÉS, M. MARTINEZ-IZQUIERDO, J.A., LUDEVID, M.D., LANGDALE, J.A., NELSON, T. and PUIGDOMĖNECH, P. (1990). Expression of a maize cell wall hydroxyproline-rich glycoprotein gene in early leaf and root vascular differentiation. Plant Cel/2: 785-793.

TAGU, D., WALKER, N., RUIZ-AVILA, L., BURGESS, S., MARTINEZ-IZQUIERDO, J.A., LEGUAY, J.J., NETTER, P. and PUIGDOMĖNECH, P. (1992). Regulation of the maize HRGP gene expression by ethylene and wounding. mRNA accumulation and qualitative expression analysis of the promoter by microprojectile bombardment. Plant Mol Biol. 20: 529-538.

TORRES, M.A., RIGAU, J. and PUIGDOMĖNECH, P. (1995). Specific distribution of mRNAs in maize growing pollen tubes observed by whole-mount in situ hybridization with non-radioactive probes. Plant J. 8: 317-321.

TZAFRIR, I., DICKERMAN, A., BRAZHNIK, O., NGUYEN, Q., MCELVER, J., FRYE, C., PATTON, D. and MEINKE, D. (2003). The Arabidopsis SeedGenes Project. Nucl. Acids Res. 31: 90-93.

VALLES, M.P., BERNUES, J., AZORÍN, F. and PUIGDOMÈNECH, P. (1991). Nuclease sensitivity of a maize HRGP gene in chromatin and in naked DNA. Plant Sci. 78: 225-230.

VERNOUD, V., HAJDUCH, M., KHALED, A.S., DEPEGE, N. and ROGOWSKY, M.P. (2005). Maize embryogenesis. Maydica 50: 469-484.

VIGNOLS, F., JOSE-ESTANYOL, M., CAPARRÓS-RUIZ, D., RIGAU, J. and PUIGDOMĖNECH, P. (1999). Involvement of a maize proline-rich protein in secondary cell wall formation as deduced from its specific mRNA localization. Plant Mol Biol. 39: 945-952.

WEIL, C. F. MONDE, R.A. TILL, R. J. COMAI, L. and HENIKOFF, S. (2005) Mutagenesis and functional genomics in maize. Maydica 50: 415-424.

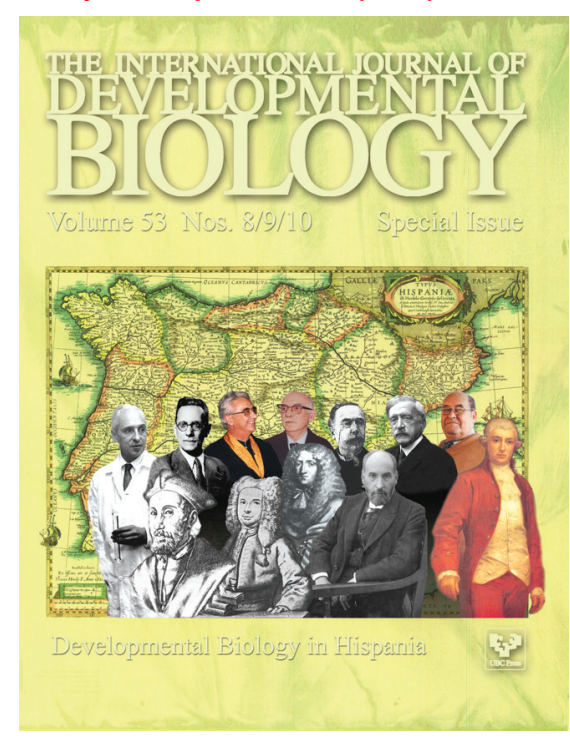




\section{Further Related Reading, published previously in the Int. J. Dev. Biol.}

See our recent Special Issue Epigenetics \& Development edited by Saadi Khochbin and Stefan Nonchev at: http://www.ijdb.ehu.es/web/contents.php?vol=53\&issue=2-3

See Special Issue Pattern Formation edited by Michael K. Richardson and Cheng-Ming Chuong at: http://www.ijdb.ehu.es/web/contents.php?vol=53\&issue=5-6

\section{Chromatin remodeling in plant development}

José A. Jarillo, Manuel Piñeiro, Pilar Cubas and José M. Martínez-Zapater Int. J. Dev. Biol. (2009) 53: 1581-1596 (doi: 10.1387/ijdb.072460jj)

Plant Developmental Biology in Spain: from the origins to our days and prospects for the future José-Pío Beltrán

Int. J. Dev. Biol. (2009) 53: 1219-1234. (doi: 10.1387/ijdb.072456jb)

Instructive roles for hormones in plant development

David Alabadí, Miguel A. Blázquez, Juan Carbonell, Cristina Ferrándiz and Miguel A. PérezAmador

Int. J. Dev. Biol. (2009) 53: 1597-1608 (doi: 10.1387/ijdb.072423da)

Seed development and inheritance studies in apomictic maize-Tripsacum hybrids reveal barriers for the transfer of apomixis into sexual crops

Olivier Leblanc, Daniel Grimanelli, Martha Hernandez-Rodriguez, Pablo A. Galindo, Ana M. Soriano-Martinez and Enrico Perotti Int. J. Dev. Biol. (2009) 53: 585-596

Seed maturation: developing an intrusive phase to accomplish a quiescent state Jesús Vicente-Carbajosa and Pilar Carbonero

Int. J. Dev. Biol. (2005) 49: 645-651.

Historical perspectives on plant developmental biology

Mieke Van Lijsebettens and Marc Van Montagu

Int. J. Dev. Biol. (2005) 49: 453-465

Young microspore-derived maize embryos show two domains with defined features also present in zygotic embryogenesis.

Pilar S Testillano, Carmen Ramírez, Jezabel Domenech, Maria-José Coronado, Phillipe Vergne, Elisabeth Matthys-Rochon and María C Risueño

Int. J. Dev. Biol. (2002) 46: 1035-1047

Gene network analysis in plant development by genomic technologies

Frank Wellmer and José Luis Riechmann

Int. J. Dev. Biol. (2005) 49: 745-759.
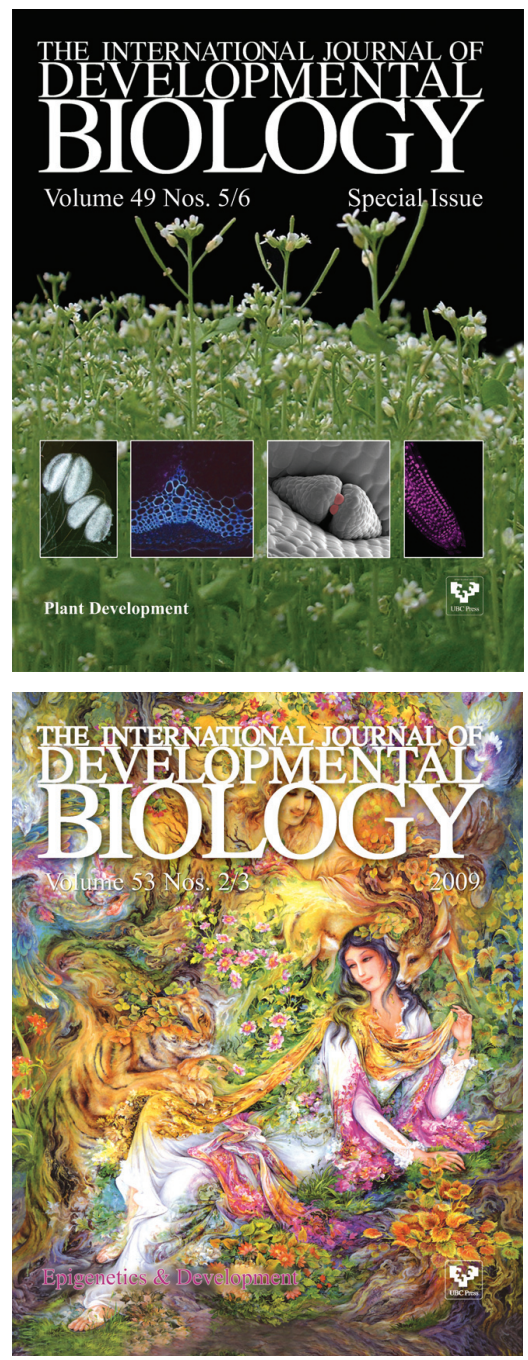

5 yr ISI Impact Factor $(2008)=3.271$

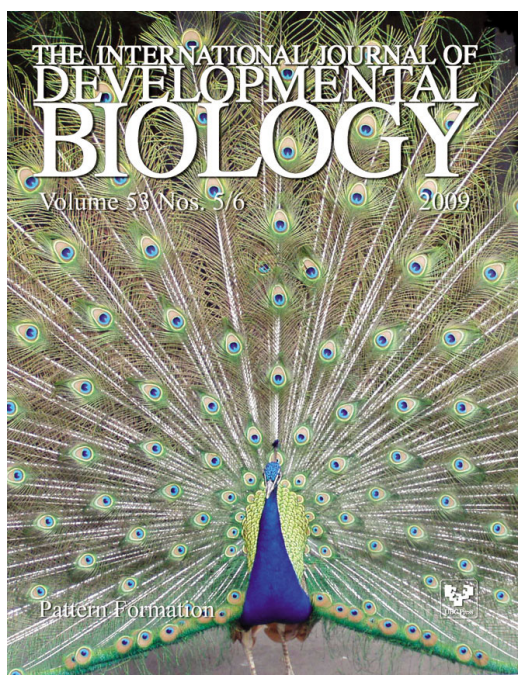

